\title{
A Unique Control Mechanism in the Regulation of Insulin Secretion Secretagogue-induced Somatostatin Receptor Recruitment
}

Boris Draznin, J. Wayne Leitner, and Karl E. Sussman

Department of Medicine and Research Service, Veterans Administration Medical Center and the University of Colorado Health Sciences Center, Denver, Colorado 80220

\begin{abstract}
In this study, we have correlated the translocation of somatostatin (SRIF) receptors from the cell interior to the plasma membrane with the ability of SRIF to inhibit insulin release. Islets were perifused with glucose $(30,100,165,200$, or 300 $\mathrm{mg} / \mathrm{dl}$ ) in the presence of sodium isethionate. Sodium isethionate inhibits insulin release, but not the recruitment of SRIF receptors. Thus, the recruitment of SRIF receptors to the surface membrane continued without the lysis of secretion vesicles. SRIF binding rose from $3.75 \pm 0.16$ to $6.46 \pm 0.28 \mathrm{fmol} /$ 10 islets as glucose concentration increased.

Sodium isethionate was then removed, islets perifused with low glucose (30 mg/dl), and challenged with $400 \mu \mathrm{M}$ isobutylmethylxanthine (IBMX) with or without SRIF (5 $\mu \mathrm{g} / \mathrm{ml})$. In the islets perifused with high glucose concentration, IBMX lysed a greater number of vesicles and caused enhanced release of insulin. The greater the number of secretion vesicles marginated to the plasma membrane by glucose, the greater the response to IBMX. Colchicine $(1 \mathrm{mM})$ prevented secretion vesicle migration and this potentiation effect of higher concentrations of glucose was eliminated.

In experiments with IBMX and SRIF, the degree of inhibition of IBMX-induced insulin release by SRIF was proportional to the magnitude of SRIF binding to these islets. SRIF inhibited insulin release by $20 \mu \mathrm{U} / 100$ islets initially perifused with low glucose $(30 \mathrm{mg} / \mathrm{dl})$ and by $875 \mu \mathrm{U} / 100$ islets perifused with high glucose $(300 \mathrm{mg} / \mathrm{dl})$. The maximal effect of SRIF was observed when its binding reached a level of $5.4 \mathrm{fmol} / 10$ islets.

We conclude that inhibition of insulin release by SRIF is proportional to the SRIF receptor concentration, and that translocation of SRIF receptors during exocytosis plays an important role in paracrine regulation of insulin secretion by rendering the islets more sensitive to SRIF.
\end{abstract}

\section{Introduction}

We have recently shown that glucose and sulfonylurea agents augment somatostatin (SRIF) ${ }^{1}$ binding in isolated pancreatic

This work was presented in part at the Annual Meeting of the American Diabetes Association, Las Vegas, NV, 10-12 June 1984.

Address reprint requests to Dr. B. Draznin, Veterans Administration Medical Center, 1055 Clermont St., Denver, CO 80220. 1985.

Received for publication 2 July 1984 and in revised form 24 January

1. Abbreviations used in this paper: AIR, acute insulin release; IBMX, isobutylmethylxanthine; NaIs, sodium isethionate; SRIF, somatostatin.

J. Clin. Invest.

(C) The American Society for Clinical Investigation, Inc. 0021-9738/85/05/1510/07 \$1.00

Volume 75, May 1985, 1510-1516 islets concomitantly with the stimulation of insulin release (1). This enhancement in SRIF binding appears to be due to an increase in SRIF receptor concentration without a change in receptor affinity (1-3). Moreover, the bulk of SRIF receptors $(80-87 \%)$ was found intracellularly, primarily in association with secretion vesicles (3-5).

We have suggested that the secretion vesicle may provide the vehicle for translocating the receptor for SRIF from the cell interior to the plasma membrane during exocytosis $(1,2)$. We further proposed that an increase in SRIF binding following an initial burst of insulin release may render the islets more sensitive to SRIF's inhibition of insulin release. If this is true, this would represent a unique control mechanism in the paracrine regulation of hormone secretion.

To test this hypothesis, we have examined the role of secretagogue-induced translocation of SRIF receptors to the plasma membrane in potentiating the biological action of SRIF in inhibiting insulin release.

\section{Methods}

Animals. Male Sprague-Dawley rats weighing 250-350 g employed in these studies were obtained from Harlan Sprague-Dawley, Inc., Indianapolis, IN. The animals were allowed food and water ad lib. Anesthesia was induced with phenobarbital $45 \mathrm{mg} / \mathrm{kg}$ body wt.

Materials. Collagenase CLS-IV $207 \mathrm{U} / \mathrm{mg}$ was obtained from the Millipore Corp., Freehold, NJ. [ $\left.{ }^{125} \mathrm{I}\right]-1$-tyrosine, SRIF $(\sim 2200 \mathrm{Ci} /$ $\mathrm{mmol} \mathrm{sp}$ act) was purchased from New England Nuclear, Boston, MA. ${ }^{125}$ I-insulin $(\sim 180 \mu \mathrm{Ci} / \mu \mathrm{g}$ sp act) was purchased from Cambridge Medical Diagnostics, Inc., Billerica, MA. Biochemicals were obtained from the Sigma Chemical Co., St. Louis, MO.

Isolation of islets. Pancreatic islets were prepared by the method of Kostianovsky and Lacy (6), with modifications of Mehler et al. (1). After isolation, the islets were kept in Krebs-Ringer bicarbonate buffer containing $30 \mathrm{mg} / \mathrm{dl}$ glucose and $5 \mathrm{mg} / \mathrm{ml}$ bovine serum albumin (BSA). The buffer had been previously gassed with $95 \% 0_{2}: 5 \% \mathrm{CO}_{2}$ for $30 \mathrm{~min}$ and adjusted to $\mathrm{pH} 7.4$

Perifusion of isolated islets. The perifusion procedure for isolated islets as detailed in a previous publication (2) was employed with the following modifications. 100 islets were loaded into each of two Swinney adapters (Millipore Corp., Bedford, MA) fitted with four layers of polyester monofilament screen (mesh 7-230-62; Tetho, Inc., Elmsford, NJ). The chambers, tubing, and medium reservoirs were maintained at $37^{\circ} \mathrm{C}$ in a water bath. The islets in the experimental and control chambers were perifused at a flow rate of $1 \mathrm{ml} / \mathrm{min}$ with a Krebs-buffered medium in which $\mathrm{NaCl}$ had been replaced with 120 $\mathrm{mM}$ sodium isethionate (NaIs) and containing $5 \mathrm{mg} / \mathrm{ml} \mathrm{BSA}$ with either $30,100,165,200$, or $300 \mathrm{mg} / \mathrm{dl}$ glucose. This pretreatment (period A) was continued for $30 \mathrm{~min}$ and effluent samples were collected at 2-min intervals using a Gilson microfractionator (Gilson Co., Inc., Worthington, OH). After the pretreatment period, the experimental and control chambers were perifused for 16 min with Krebs buffer containing $120 \mathrm{mM} \mathrm{NaCl}$ instead of $\mathrm{NaIs}, 5 \mathrm{mg} / \mathrm{ml} \mathrm{BSA}$, and $30 \mathrm{mg} / \mathrm{dl}$ glucose (period B). Effluent samples were collected as before. The islets in the control chamber were finally perifused with a 
Krebs-buffered medium containing $120 \mathrm{mM} \mathrm{NaCl}, 5 \mathrm{mg} / \mathrm{ml} \mathrm{BSA}, 30$ $\mathrm{mg} / \mathrm{dl}$ glucose, and $400 \mu \mathrm{M}$ isobutylmethylxanthine (IBMX) for an additional $16 \mathrm{~min}$ (period $\mathrm{C}$ ), collecting effluents as before. During period $C$, the experimental chambers were perifused for $16 \mathrm{~min}$ with the same Krebs-buffered medium as control islets, but which also contained $5 \mu \mathrm{g} / \mathrm{ml} \mathrm{SRIF}$. All effluent samples from the islet perifusion were collected and maintained at $2^{\circ} \mathrm{C}$. These effluents were saved for determination of insulin release by double-antibody radioimmunoassay (7)

Static islet incubations. Static islet incubations were performed as described in a previous publication (8). Following a 30-min preincubation and a 16-min base-line incubation in gassed Krebs-Ringer buffer with $30 \mathrm{mg} / \mathrm{dl}$ glucose and $5 \mathrm{mg} / \mathrm{ml} \mathrm{BSA}$ at $37^{\circ} \mathrm{C}$, buffered Krebs-Ringer containing sufficient glucose to yield a final concentration of either $30,100,165,200$, or $300 \mathrm{mg} / \mathrm{dl}$ was added at 15 -s intervals. The islets were incubated at $37^{\circ} \mathrm{C}$ for an additional $16 \mathrm{~min}$. After this experimental phase, aliquots of supernatant were removed for insulin assay.

The islets were washed and ${ }^{125}$ I-SRIF binding was determined as previously described $(1,2,8)$. Binding reaction was carried out for $16 \mathrm{~h}$ at $4^{\circ} \mathrm{C}$. Specific binding was calculated as the difference between the samples containing 0 and $10 \mu \mathrm{g} / \mathrm{ml}$ unlabeled SRIF; these representing total binding and nonspecific binding, respectively. Statistical analyses were performed utilizing Student's $t$ test for paired and unpaired data as indicated.

\section{Results}

Initially, we examined the effect of increasing concentrations of glucose $(30,100,165,200$, and $300 \mathrm{mg} / \mathrm{dl})$ upon insulin release and SRIF binding in isolated pancreatic islets. The results of these experiments are depicted on Fig. 1. An increase in glucose concentration in the incubation media prompted a significant increase in insulin release (Fig. $1 A$ ) and SRIF binding (Fig. $1 B$ ). The dose-response curves were parallel and reached a plateau at a glucose concentration of $200 \mathrm{mg} / \mathrm{dl}$. There was a direct and significant correlation $(r=0.77 ; P$ $<0.001$ ) between glucose-induced insulin release and enhancement of SRIF receptor recruitment. In these and other experiments, we were unable to detect any stimulation of SRIF release from freshly isolated pancreatic islets (not shown).

Following a protocol previously described (9), we then attempted to translocate secretion vesicles from the cell interior to the plasma membrane without prompting insulin release.
Table I. Effect of NaIs* on Glucose-induced Insulin Release and Recruitment of SRIF Receptors

\begin{tabular}{|c|c|c|c|c|}
\hline \multirow[b]{2}{*}{ Glucose concentration } & \multicolumn{2}{|c|}{$\begin{array}{l}\mathrm{NaIs} / \mathrm{NaCl} \\
(0 / 120 \mathrm{mM})\end{array}$} & \multicolumn{2}{|c|}{$\begin{array}{l}\mathrm{NaIs} / \mathrm{NaCl} \\
(120 / 0 \mathrm{mM})\end{array}$} \\
\hline & IR & B & IR & B \\
\hline & $\mu U / m l$ & $\%$ & $\mu U / m l$ & $\%$ \\
\hline $30 \mathrm{mg} / \mathrm{dl}(n=8)$ & $130 \pm 15$ & $2.8 \pm 0.3$ & $150 \pm 18$ & $3.1 \pm 0.3$ \\
\hline $300 \mathrm{mg} / \mathrm{dl}(n=8)$ & $480 \pm 25$ & $7.3 \pm 0.5$ & $180 \pm 21$ & $7.2 \pm 0.4$ \\
\hline
\end{tabular}

B, SRIF receptors; IR, insulin release.

* Substitution of $\mathrm{NaIs}(120 \mathrm{mM})$ for $\mathrm{NaCl}$ in the incubation media results in inhibition of exocytotic hormone release (9-11). NaIs is an impermeant anion that blocks lysis of secretion vesicles. " $n$ " represents the number of experiments.

This is achieved by substituting $\mathrm{NaIs}$ for $\mathrm{NaCl}$ in the incubation media. NaIs is an impermeant anion which blocks osmotic lysis of secretion vesicles and thus inhibits exocytotic hormone release $(10,11)$. Under the circumstances, we would expect an increase in surface membrane SRIF binding with no alteration in the magnitude of insulin release.

Results of these experiments are summarized in Table I. Islets incubated with NaIs and high concentration of glucose $(300 \mathrm{mg} / \mathrm{dl})$ did not release insulin above the basal rate. However, enhancement of SRIF binding continued, suggesting a continuous margination of secretion vesicles at the plasma membrane.

Having established the method for increasing translocation of the secretion granules to the plasma membrane, we reasoned that islets incubated under these conditions would demonstrate a greater response to a stimulus that produces acute insulin release (AIR). Thus, at any given level of insulin secretagogue, the magnitude of AIR would increase depending upon the number of secretion vesicles marginated at the plasma membrane.

We have selected IBMX because we have previously shown that this agent causes prompt lysis of previously marginated secretion vesicles (8). In these experiments, islets were perifused
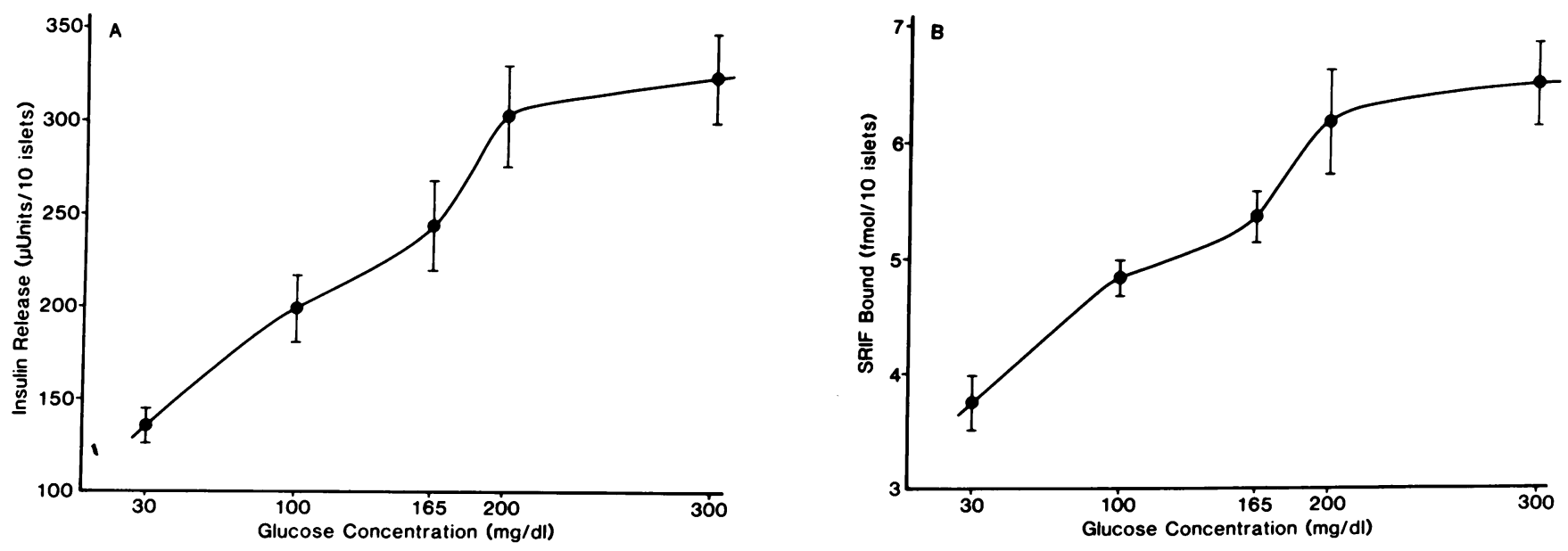

Figure 1. Effect of increasing glucose concentrations on insulin release $(A)$ and SRIF binding $(B)$ in isolated pancreatic islets. Results represent the mean \pm SEM of 12 experiments. 
(30 min) with increasing concentrations of glucose in the presence of Nals to insure translocation of secretion vesicles to the plasma membrane without concomitant lysis (period A). Following a 16-min washout period (B), the islets were challenged with $400 \mu \mathrm{M}$ IBMX (16 min) in the presence of a nonstimulatory level of glucose and in the absence of NaIs (period C). Fig. 2 demonstrates that islets initially perifused with higher glucose concentrations responded to the subsequent challenge with IBMX with greater insulin release than islets initially perifused at lower glucose concentrations.

To insure that glucose-induced potentiation of IBMX evoked insulin release was indeed a consequence of secretion vesicle translocation, we have perifused pancreatic islets with high glucose concentrations $(300 \mathrm{mg} / \mathrm{dl})$ and $\mathrm{NaIs}$ as described above, but in the presence of colchicine $(1 \mathrm{mM})$. Colchicine at the concentration employed is known to suppress microtubule function and secretion vesicle margination (2). When control and colchicine-treated islets were challenged with IBMX, there was a significant reduction in the magnitude of AIR from the islets perifused with colchicine (Fig. 3).

Utilizing essentially the same experimental design for promoting the recruitment of SRIF receptors (i.e., increasing concentrations of glucose in the presence of NaIs), we then posed the question of whether this increase in SRIF receptor binding results in greater biological action of SRIF. To answer this question, we perifused pancreatic islets with increasing concentrations of glucose and $120 \mathrm{mM}$ NaIs (period A). After a washout (period B), we challenged the islets with IBMX (400 $\mu \mathrm{M})$ in the presence of SRIF $(5 \mu \mathrm{g} / \mathrm{ml})$ (period C).

As can be seen from Fig. 4, in all perifusion experiments (except those with glucose $30 \mathrm{mg} / \mathrm{dl}$ ), SRIF inhibited IBMXinduced insulin release. The inhibitory action of somatostatin was greater in the islets perifused with a higher glucose concentration during period A. As glucose concentration rose, the recruitment of SRIF receptors was enhanced and an inhibitory effect of SRIF was significantly augmented.

When the results of these experiments were expressed as

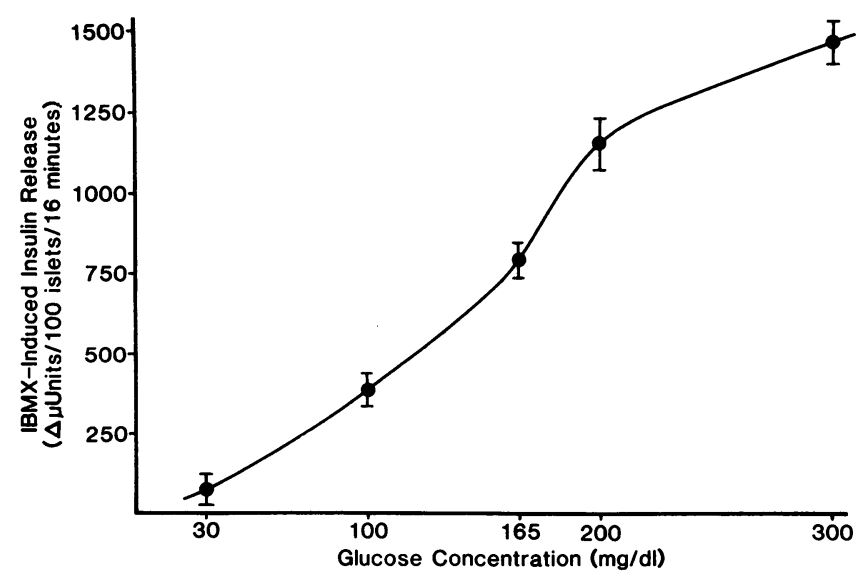

Figure 2. Glucose potentiation of IBMX-induced insulin release. Islets were perifused with increasing concentrations of glucose and $120 \mathrm{mM}$ NaIs (period A), washed with $30 \mathrm{mg} / \mathrm{dl}$ glucose and 120 $\mathrm{mM} \mathrm{NaCl}$ (period B), and challenged with $400 \mu \mathrm{M}$ IBMX (period C). The difference in insulin release between periods $C$ and $B$ is plotted as a function of glucose concentration during period $\mathrm{A}$. Results represent the mean \pm SEM of four perifusion experiments.

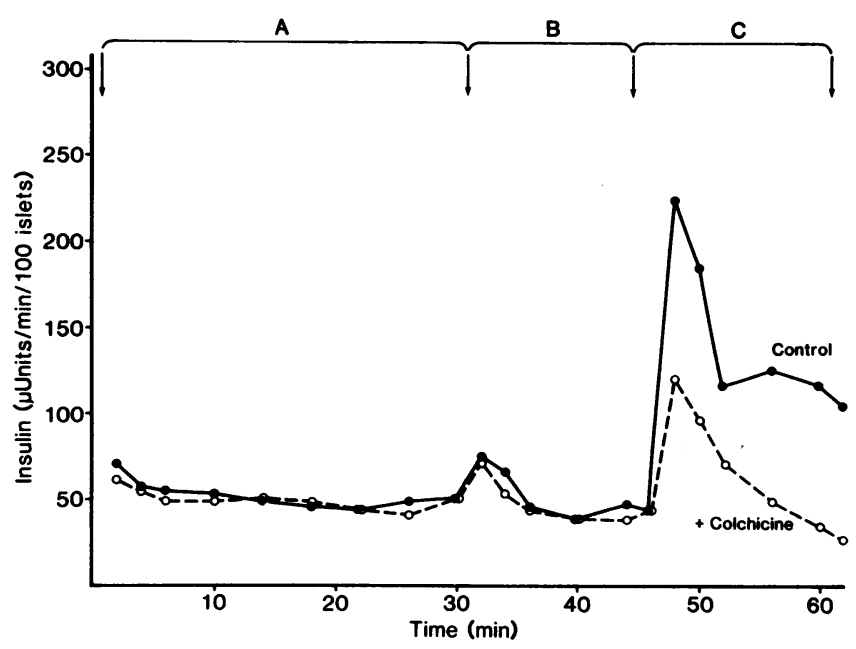

Figure 3. Effect of colchicine $(1 \mathrm{mM})$ on glucose potentiation of IBMX-induced insulin release. Glucose concentration during period A was $300 \mathrm{mg} / \mathrm{dl}$. Results represent mean values of four perifusions.

the IBMX-induced increments (insulin release during period C) above the basal rate of insulin release (period B), an increasing inhibitory effect of SRIF as a function of glucose concentration during period A was especially well demonstrated. Islets perifused at higher glucose concentrations during period A demonstrated a progressive increase in the magnitude of somatostatin inhibition of IBMX-induced insulin release (Fig. 5). However, the percent inhibition tended to plateau when somatostatin binding reach a level of $5.4 \mathrm{fmol} / 10$ islets (Fig. 6). $50 \%$ inhibition of IBMX-induced insulin release was observed when the binding of somatostatin reached a level of 4.8 $\mathrm{fmol} / 10$ islets.

Our control experiments were designed to evaluate the effect of a fixed dose of somatostatin on insulin release prompted by increasing stimuli when there was no enhancement in SRIF receptor recruitment. In these experiments, islets were initially perifused (period A) with low glucose $(30 \mathrm{mg} / \mathrm{dl})$ for $30 \mathrm{~min}$, then with low glucose and SRIF $(5 \mu \mathrm{g} / \mathrm{ml})$ for $10 \mathrm{~min}$ (period B), and finally with increasing concentrations of glucose $(100,165$, and $300 \mathrm{mg} / \mathrm{dl}), \operatorname{IBMX}(400 \mu \mathrm{M})$, and SRIF (5 $\mu \mathrm{g} /$ $\mathrm{ml})$. Results of these experiments are shown in Figs. 7 and 8. Increasing concentrations of glucose along with fixed dose of IBMX caused a progressive increase in insulin release. Somatostatin inhibited secretagogue-induced insulin release with the percent inhibition being identical in all perifusions, regardless of glucose concentration. These experiments suggested that without SRIF receptor recruitment no augmentation of SRIF action is observed.

\section{Discussion}

The anatomic relationships among different cell types in endocrine pancreas may be crucial for coordinating secretion of polypeptide hormones. Direct communication among islet cells and the influence of the product of one cell type upon the secretion of hormone by the neighboring cells in the endocrine pancreas has been well established $(12,13)$. The assumption has been that the secretory product of one hormoneproducing cell is transported to an adjacent hormone-containing 

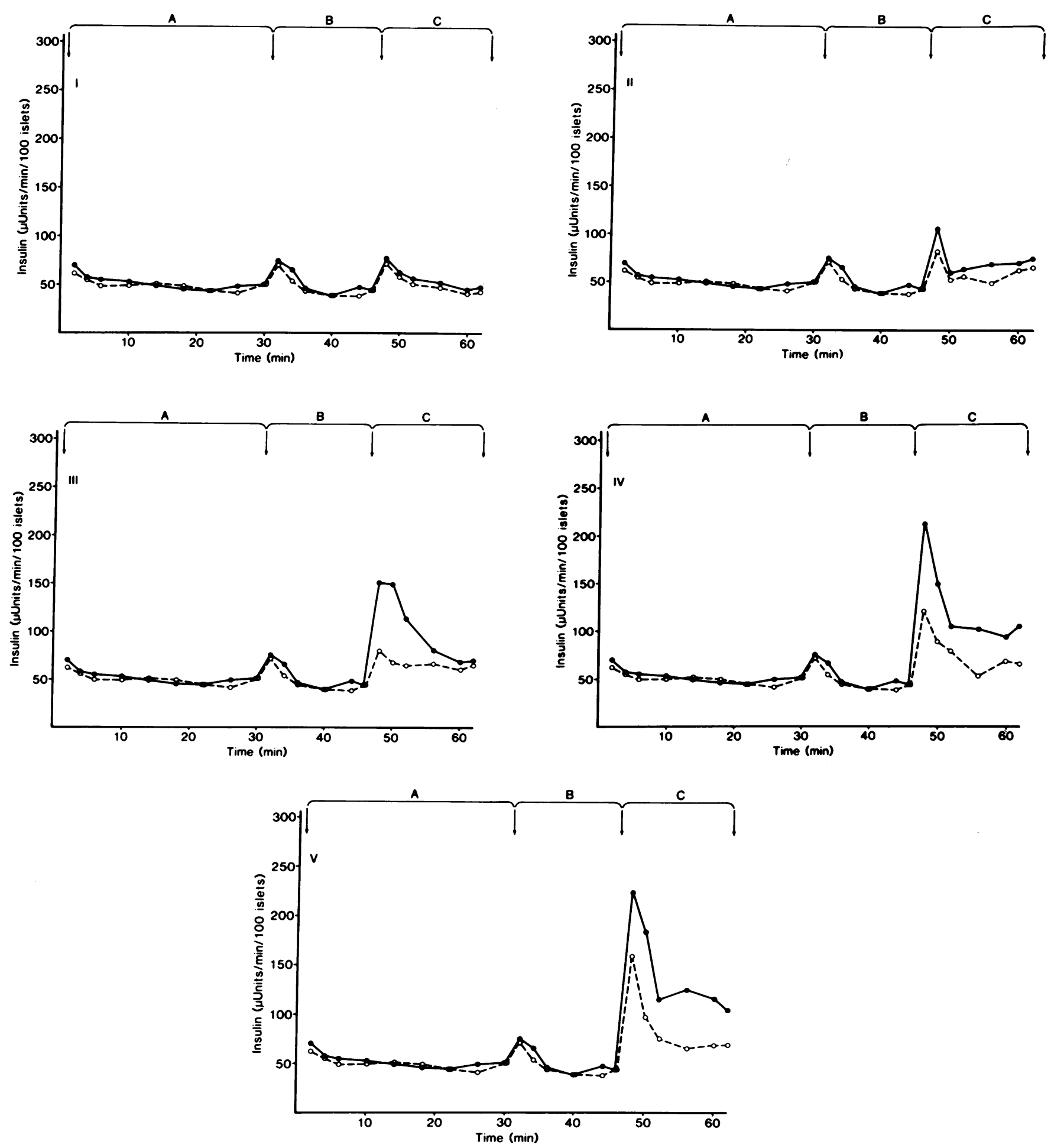

Figure 4. Somatostatin inhibition of IBMX-induced insulin release. Glucose concentrations during period A were $30 \mathrm{mg} / \mathrm{dl}$ (I), $100 \mathrm{mg} /$ dl (II), $165 \mathrm{mg} / \mathrm{dl}$ (III), $200 \mathrm{mg} / \mathrm{dl}$ (IV), and $300 \mathrm{mg} / \mathrm{dl}$ (V). Ingredients used during periods $\mathrm{B}$ and $\mathrm{C}$ are as described in Methods and the legend to Fig. 3. Perifusion during period $\mathrm{C}$ were carried out with $\left(---0_{---)}\right.$or without $(-\bullet-)$ SRIF $(5 \mu \mathrm{g} / \mathrm{ml})$. Each panel represents the mean values of four perifusions.

Glucose-induced stimulation of SRIF release from the pancreas has been previously shown $(14,15)$. However, in experiments with isolated pancreatic islets, we were unable to detect any increase in SRIF release. It is possible that small increments in intra-islet SRIF concentration do exist, but they 


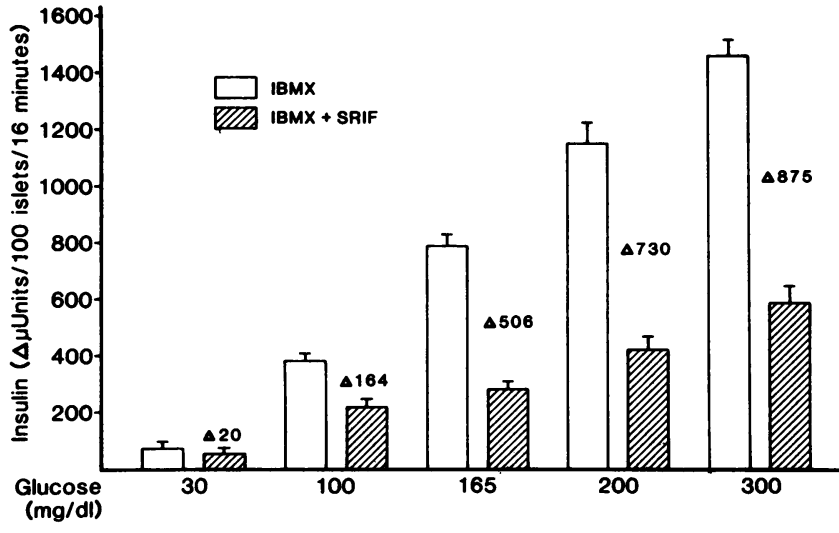

Figure 5. Effect of SRIF on IBMX-induced insulin release as a function of glucose concentration during period A perifusion. Insulin release is shown as the difference between periods $C$ and $B$. Results represent the mean \pm SEM of four perifusions in each experimental group.

are undetectable in perfusate or incubation media. Even though we failed to detect glucose-induced SRIF release, in our static incubations we have washed the islets after the exposure to secretagogues and before assessment of SRIF binding. Similarly during perifusion experiments, the period B (washing) was employed to eliminate the possible influence of endogenous SRIF on insulin release during period $C$.

Our results do not negate the model of paracrine regulation based upon augmentation in release of both hormones, but nevertheless they favor an alternate model being responsible for the paracrine regulation of insulin secretion (Fig. 9).

When glucose stimulates insulin release, it concomitantly enhances translocation of SRIF receptors from the cell interior to the plasma membrane. This renders insulin-secreting cells more sensitive to SRIF. This putative pathway in paracrine regulation would have certain advantages in the cellular control

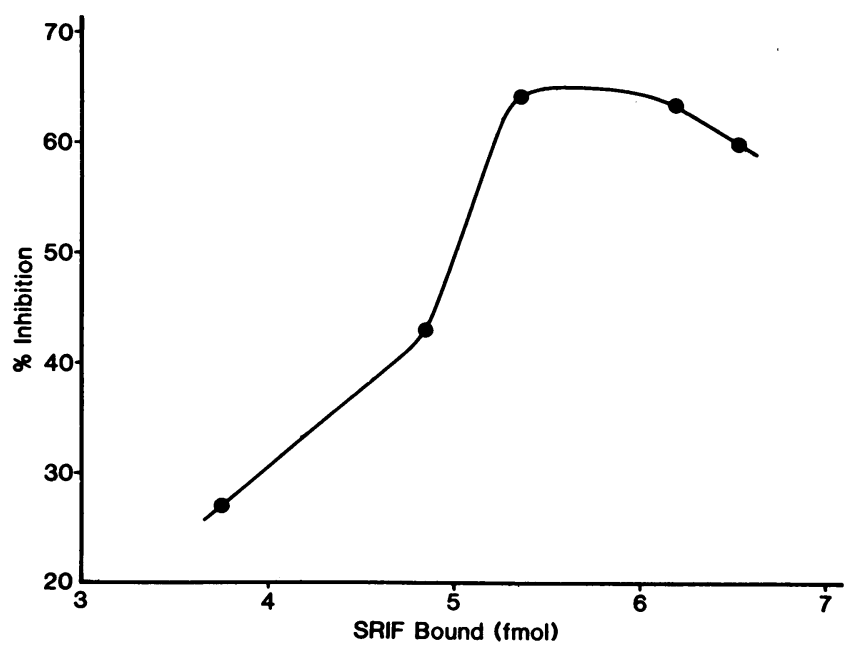

Figure 6. Relationship between SRIF binding and action. The latter is expressed as a percent inhibition of IBMX-induced insulin release following perifusion with increasing glucose concentrations and plotted against SRIF binding at similar concentrations of glucose. Results represent the mean values of four experiments.

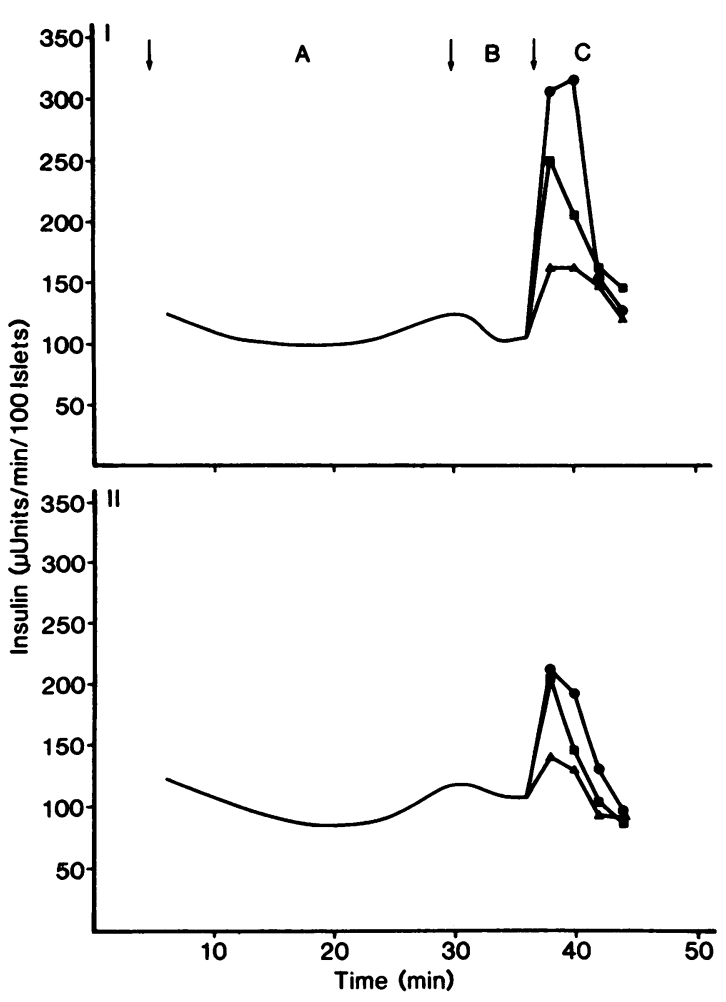

Figure 7. Insulin release in the absence (1) and in the presence (11) of SRIF in perfusate during periods B and C. During period A, the islets were perifused with glucose $(30 \mathrm{mg} / \mathrm{dl})$ alone, and during period $\mathrm{C}$, with glucose $(\triangle, 30 \mathrm{mg} / \mathrm{dl} ; \mathrm{m}, 165 \mathrm{mg} / \mathrm{dl}$; or $\bullet, 300 \mathrm{mg} / \mathrm{dl})$ and 400 $\mu M$ IBMX. SRIF (5 $\mu \mathrm{g} / \mathrm{ml})$ was present during periods $B$ and $C$ in perifusions depicted on the lower panel. Results are mean values of four perifusions.

of hormone secretion. SRIF would be acting at a specific anatomic locus in inhibiting hormone release, the juncture of the secretion vesicle with the surface membrane. Augmented SRIF release from the delta cell would not be required. The effect of SRIF in inhibiting hormone release would be closely integrated with the exocytotic secretory process. The concentration of SRIF receptors at the surface membrane is a function of the combined processes of appearance of receptors at the plasma membrane and the rate of receptor internalization. Theoretically, in the scheme being proposed, the secretagogue regulates the appearance of receptors at the surface membrane.

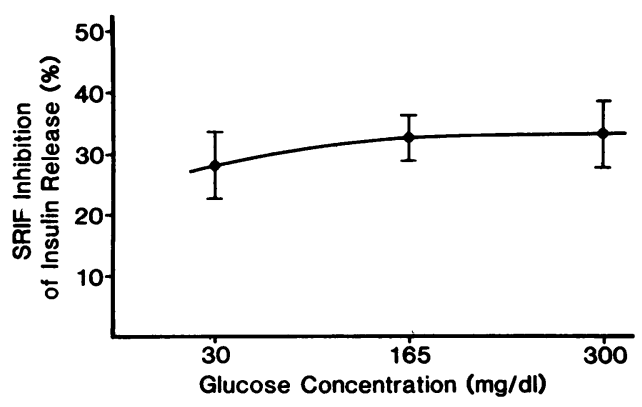

Figure 8. SRIF inhibition of insulin release. Data derived from the experiments depicted in Fig. 7. 


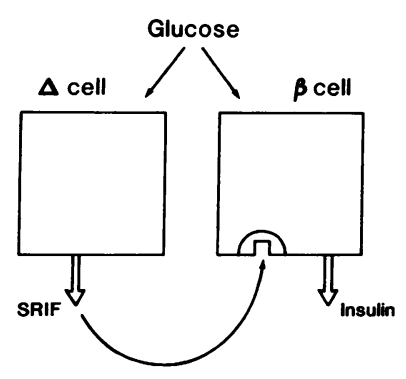

Concentration-Dependent Paracrine Regulation

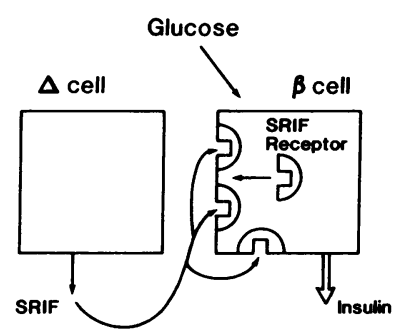

Receptor-Dependent Paracrine Regulation

Figure 9. Schematic representation of two models of paracrine regulation in pancreatic islets.

The combining of SRIF with its receptor would probably accelerate the rate of receptor internalization, thus giving rise to a well-integrated system.

Our theory is supported by direct demonstration of the receptor sites for insulin, glucagon, and SRIF on the surface of $A, B$, and D cells (16). In these studies ${ }^{125}$ I-insulin was shown to associate with $60 \%$ of the B cells, $35 \%$ of the A cells, and $22 \%$ of the D cells. ${ }^{125}$ I-glucagon was found in $40 \%$ of the B cells, $15 \%$ of the A cells, and $31 \%$ of the D cells. ${ }^{125}$ I-SRIF labeled $75 \%$ of A cells, $37 \%$ of B cells, and $33 \%$ of D cells. Moreover, the present study provides the first evidence that SRIF receptors can actively participate in regulation of hormone secretion.

Recent morphological (17) and biochemical (18) observations suggested that SRIF released by D cells may not gain an access to the B cells via an intestitium. Rather, it is collected by the venules leaving the islet, and the only active SRIF is that delivered to the islets by the arterioles. This theory also implies that the exocytosis in B cells occurs into the "venous" space while receptors for regulatory hormones are on the arterial surface. If this is the case, then one must assume not only polarity of the cells for exocytotic purposes, but also a complete separation of "venous" and "arterial" compartments of the interstitium. Further experiments are needed to prove or rule out these assumptions.

The results of our experiments may provide some new insights into the mechanism of glucose potentiation of AIR evoked by other secretagogues, such as IBMX, isoproterenol, and arginine. This phenomenon has been recognized and extensively studied by Halter and Porte $(19,20)$. Our present and previous studies $(8,9)$ suggest that glucose directly enhances the migration of secretion vesicles from the cell interior to the plasma membrane, thus providing a greater pool of marginated secretion vesicles. Secretagogues that evoke an AIR act upon these previously marginated granules, causing their lysis and prompt insulin release (8). As can be seen from the present study, when islets were incubated with increasing concentrations of glucose and NaIs, glucose enhanced translocation of secretion vesicles in a dose-dependent manner. Subsequently, in islets perifused with a higher glucose concentration, IBMX lysed a greater number of vesicles and caused enhanced release of insulin. The greater the number of secretion vesicles marginated to the plasma membrane by glucose, the greater the response to IBMX. Colchicine prevented secretion vesicle migration

and this potentiation effect of higher concentrations of glucose was eliminated.

Our interpretation of the data presented here is based on the assumption that alterations in binding signify margination of the secretion vesicles. Although we have previously presented an ample evidence in favor of this assumption $(2-4,9)$, we cannot completely exclude the possibility that there might be other intracellular binding sites for SRIF that migrate to the plasma membrane during exocytosis.

In summary, glucose-induced margination of secretion vesicles in the pancreatic islets facilitates the acute insulin response to other stimuli. In addition, margination of secretion vesicles to the plasma membrane recruits SRIF receptors and renders these islets more sensitive to an inhibitory action of SRIF. The latter feedback mechanism may be an important mechanism in the paracrine regulation of hormone secretion.

\section{Acknowledgments}

The authors wish to thank Evelyn Fitzgerald for her excellent secretarial assistance.

This work was supported by the research funds from the Veterans Administration, National Institutes of Health (AM 32006), and Diabetes Research Foundation of Colorado. Dr. Draznin is a recipient of the Clinical Investigator Award from the Veterans Administration.

\section{References}

1. Mehler, P. S., A. L. Sussman, A. Maman, J. W. Leitner, and K. E. Sussman. 1980. Role of insulin secretagogue in the regulation of somatostatin binding by isolated rat islets. J. Clin. Invest. 66:1334 1338.

2. Sussman, K. E., P. S. Mehler, J. W. Leitner, and B. Draznin. 1982. Role of the secretion vesicle in the transport of receptors: modulation of somatostatin binding to pancreatic islets. Endocrinology. 111:316-323.

3. Sussman, K. E., B. Draznin, J. W. Leitner, and P. S. Mehler. 1982. The endocrine secretion granule revisited-postulating new functions. Metab. Clin. Exp. 31:959-967.

4. Draznin, B., J. W. Leitner, and K. E. Sussman. 1982. Kinetics of somatostatin receptor migration in isolated pancreatic islets. Diabetes. 31:467-469.

5. Leitner, J. W., R. M. Rifkin, A. Maman, and K. E. Sussman. 1980. The relationship between somatostatin binding and cyclic AMPstimulated protein kinase inhibition. Metab. Clin. Exp. 29:1065-1074.

6. Lacy, P. E., and M. Kostianovsky. 1967. Method for isolation of intact islets of Langerhans from the rat pancreas. Diabetes. 16:3539.

7. Morgan, C. R., and A. Lazarow. 1963. Immunoassay of insulin to antibody system plasma insulin level in normal, subdiabetic and diabetic rats. Diabetes. 12:115-126.

8. Steinberg, J. P., J. W. Leitner, B. Draznin, and K. E. Sussman. 1984. Calmodulin and cyclic AMP: possible different sites of action of these two regulatory agents in exocytotic hormone release. Diabetes. 33:339-345.

9. Sussman, K. E., H. B. Pollard, J. W. Leitner, R. Nesher, J. Adler, and E. Cerasi. 1983. Differential control of insulin secretion and somatostatin-receptor recruitment in isolated pancreatic islets. Biochem. J. 214:225-230.

10. Pollard, H. B., C. J. Pazoles, C. E. Creutz, and O. Zinder. 1979. The chromaffin granule and possible mechanism of exocytosis. Int. Rev. Cytol. 58:160-198. 
11. Orci, L., and W. Malaisse. 1980. Single and chain release of insulin secretory granules is related to anion transport at exocytotic sites. Diabetes. 29:943-944.

12. Orci, L., and R. H. Unger. 1975. Functional subdivision of islets of Langerhans and possible role of D-cells. Lancet. II:1243-1244.

13. Unger, R. H. 1981. The milieu interieur and the islets of Langerhans. Diabetologia. 20:1-11.

14. Zyznar, E. S., A. O. Pietri, V. Harris, and R. H. Unger. 1981. Evidence for the hormonal status of somatostatin in man. Diabetes. 30:883-886.

15. Green, I. C., D. Perrin, E. Penman, A. Yaseen, K. Ray, and S. L. Howell. 1983. Effect of dynorphin on insulin and somatostatin secretion, calcium uptake and C-AMP levels in isolated rat islets of Langerhans. Diabetes. 32:685-690.

16. Pattel, Y. C., M. Amherdt, and L. Orci. 1982. Quantitative electronmicroscopic autoradiography of insulin, glucagon, and somatostatin binding sites on islets. Science (Wash. DC). 217:1155-1156.

17. Bonner-Weir, S., and L. Orci. 1982. New prospectives on the microvasculature of the islets of Langerhans in the rat. Diabetes. 31: 883-889.

18. Kawai, K., E. Ipp, L. Orci, A. Perrelet, and R. H. Unger. 1982. Circulating somatostatin acts on the islets of Langerhans by way of a somatostatin poor compartment. Science (Wash. DC). 218:477-478.

19. Halter, J. B., and D. Porte, Jr. 1978. Mechanisms of impaired acute insulin release in adult onset diabetes: studies with isoproterenol and secretin. J. Clin. Endocrinol. Metab. 46:952-960.

20. Halter, J. B., R. J. Graf, and D. Porte, Jr. 1979. Potentiation of insulin secretory response by plasma glucose level in man: evidence that hyperglycemia in diabetes compensates for impaired glucose potentiation. J. Clin. Endocrinol. Metab. 48:946-954. 